\title{
Kemampuan Menulis Teks Cerita pada Mahasiswa Program Sarjana Pendidikan Bahasa Indonesia Fakultas Keguruan dan Ilmu Pendidikan Universitas Bengkulu
}

\author{
The Ability to Write Story Text of the Indonesian Language Education \\ Undergraduate Program Students, Faculty of Teacher Training and Education, \\ Bengkulu University \\ Didi Yulistio \\ Prodi Pendidikan Bahasa Indonesia, Fakultas Keguruan dan Ilmu Pendidikan, \\ Universitas Bengkulu, Indonesia \\ Pos-el: yulistiodidi@unib.ac.id
}

\section{Naskah Diterima Tanggal 27 Juni 2021-Direvisi Akhir Tanggal 12 Desember 2021-Disetujui Tanggal}

12 Desember 2021

\begin{abstract}
Abstrak
Abstrak. Tujuan penelitian ini untuk mendeskripsikan kemampuan menulis teks cerita mahasiswa Program Sarjana Pendidikan Bahasa Indonesia FKIP Universitas Bengkulu. Ruang lingkup penelitian ini mencakup aspek (1) kesesuaian tema dengan isi, (2) struktur teks cerita, (3) pilihan kata (diksi), (4) penggunaan kalimat bergaya bahasa cerita, dan (5) ejaan BI dan tulisan tangan. Penelitian ini menggunakan metode deskriptif dan pendekatan kuantitatif. Populasi penelitian semua mahasiswa Prodi Pendidikan Bahasa Indonesia FKIP Universitas Bengkulu semester ganjil 2018/2019 dan sampel secara purposive sampling, menetapkan mahasiswa semester III-A sebanyak 34 orang. Pengumpulan data menggunakan teknik tes dengan instrumen berupa petunjuk menulis cerita dengan tema "kasih sayang" dan pedoman penilaian kemampuan menulis cerita berdasarkan lima komponen, meliputi isi, struktur teks, diksi, kalimat, dan mekanik. Analisis data menggunakan statistik deskriptif untuk mencari rerata dan ditentukan hasil kualitatif. Hasil penelitian diperoleh bahwa kemampuan menulis teks cerita mahasiswa Program Sarjana Pendidikan Bahasa Indonesia FKIP Universitas Bengkulu berkategori baik. Hal ini didasarkan pada skor semua komponen dengan rerata sebesar 73,97. Hasil tersebut masih memerlukan upaya peningkatan agar lebih baik. Hasil tiap aspek kemampuan menulis teks cerita, yakni aspek (1) kesesuaian tema dengan isi berkategori baik $(18,94)$, (2) struktur cerita berkategori baik $(16,09)$, (3) ketepatan diksi berkategori baik (skor 14,3), (4) kalimat bergaya bahasa cerita berkategori baik $(17,24)$, dan (5) mekanik (ejaan BI dan tulisan tangan) berkategori baik $(7,32)$.
\end{abstract}

Kata kunci: Kemampuan; Teks; Cerita; Menulis; Bahasa Indonesia.

\section{Abstract}

The purpose of this study is to describe the ability to write story texts for students of the Indonesian Language Education Undergraduate Program FKIP Bengkulu University. The scope of this research covers aspects of (1) the suitability of the theme with the content, (2) the structure of the story text, (3) the choice of words (diction), (4) the use of story-style sentences, and (5) the Indonesian Language spelling and handwriting. This research uses descriptive method and quantitative approach. The research population was all students of the Indonesian Language Education Study Program FKIP Bengkulu University in the odd semester of 2018/2019 and the sample was purposive sampling, determining that there were 34 students in semester III-A. Collecting data uses test techniques and instruments in the form of instructions for writing stories with the theme of "love" and guidelines for assessing the ability to write stories based on five 
components, including content, text structure, diction, sentences, and mechanics. Data analysis used descriptive statistics to find the mean and determined qualitative results. The results showed that the ability to write story texts for the students of the Indonesian Language Education Undergraduate Program, FKIP Bengkulu University, was categorized as good. This is based on the score of all components with an average of 73.97. These results still require efforts to improve to be better. The results of each aspect of the ability to write story texts, namely aspects (1) the suitability of the theme with the content, good category (18.94), (2) story structure, good category (16.09), (3) accuracy of diction in good category (score 14,3$)$, (4) narrative language style sentences are in good category (17.24), and (5) mechanics (BI spelling and handwriting) are in good category (7.32).

Keywords: Ability; Text; Story; Writing; Indonesian

\section{PENDAHULUAN}

Hasil kegiatan proses pembelajaran tidak hanya ditentukan dari pencapaian keberhasilan siswanya, tetapi juga ditentukan oleh kualitas guru yang mengajar di kelas. Hasil pembelajaran bahasa Indonesia yang berkualitas juga memerlukan guru yang berkualitas. Artinya, hasil pembelajaran berkualitas dapat dicapai ketika dikelola oleh guru bahasa Indonesia yang juga berkualitas. Kualifikasi guru bahasa Indonesia yang demikian tentu bermuara atau berawal dari proses pendidikan yang dilakukan di lembaga pendidikan tenaga kependidikan (LPTK) termasuk dalam hal ini FKIP sebagai lembaga yang turut melahirkan calon pendidik. Pendidikan guru harus sudah tidak lagi mengedepankan "cetak guru”, tetapi perlu mencetak pendidik yang memiliki kompetensi pendidik sesuai dengan tuntutan UU Nomor 14 Tahun 2005 tentang Profesionalisme Guru. Menurut undang-undang ini bahwa guru adalah pendidik profesional yang memiliki kompetensi (pedagogik, akademik, kepribadian, dan sosial). Oleh karena itu, perguruan tinggi atau FKIP perlu melahirkan pendidik yang berwawasan kritis-kreatif dalam bidang ilmunya atau berkompetensi akademik dan mampu mengajarkannya secara baik atau berkompetensi pedagogi sedangkan kompetensi kepribadian dan sosial diharapkan terbentuk secara mandiri dalam proses bersosialisasi dan bekerja di masyarakat dengan kepribadiannya sendiri dalam mendidik dan mengajar anak bangsa.

Lembaga pendidikan calon guru harus membekali pengetahuan dan keterampilan serta sikap untuk memacu prestasi mahasiswanya. Mahasiswa diharapkan berprestasi dalam menyiapkan dirinya untuk mandiri. Mahasiswa bahasa Indonesia harus memiliki kemampuan dasar mengajar, merencanakan dan melaksanakan pembelajaran dalam bidang keilmuan bahasa Indonesia (keterampilan berbahasa, pengajaran bahasa, kebahasaan dan kesastraan). Cooper (dalam Satori, 2009) menegaskan bahwa kemampuan dasar guru profesional ini meliputi empat komponen, yakni (1) memiliki pengetahuan praktik belajar dan mengajar (teaching and learning), (2) memiliki pengetahuan bidang keilmuannya, (3) memiliki keterampilan mengajarkan materi bidang ilmunya, dan (4) memiliki perilaku sosial yang baik terhadap diri sendiri, teman sejawat, dan sesama, serta lingkungannya. Mahasiswa calon guru bahasa Indonesia harus mempelajari tujuan pembelajaran sesuai dengan kurikulum 2013 bidang studi bahasa Indonesia agar mampu menguraikan dan menjabarkan 
berbagai materi pelajaran sesuai dengan tujuan pembelajaran yang akan dicapai. Penguasaan materi pembelajaran keterampilan berbahasa, seperti menulis teks perlu dilakukan dalam perkuliahan agar tidak canggung ketika menerapkan di sekolah. Bahkan, akan memantapkan kompetensi akademik dan memperkuat penguasaan kompetensi pedagogi.

Pembelajaran bahasa Indonesia sesuai kurikulum 2013 saat ini berbasis teks. Artinya, kegiatan pembelajaran mengacu pada penguasaan teks untuk memenuhi tuntutan capaiannya, yakni kemampuan menulis teks sesuai dengan jenisnya, seperti menulis teks laporan hasil observasi, deskripsi, eksposisi, eksplanasi, prosedur, biografi, narasi atau cerita, dan lain-lain sesuai dengan tingkat pendidikan. Pembelajaran menulis berbasis teks ini juga dimaksudkan untuk mencapai kemampuan berpikir peserta didik. Hal ini mengingat tingkat literasi (membacamenulis) siswa kita secara nasional sesuai dengan pencapaian level PISA bahasa tahun 2012 rata-rata hanya berada pada level 3, sementara negara lain di Asia Tenggara sudah di atasnya (hasil PISA 2009; 2012). Di samping itu, capaian siswa belum membanggakan pada UN bahasa Indonesia berbasis KTSP dan kurikulum 2013 (tahun 2017) serta hasil studi organisasi internasional, seperti TIMMS, bahwa sebagian besar siswa Indonesia hanya mampu menjawab persoalan pada level menengah (sebanyak 95\%), sedangkan kemampuan siswa dalam menjawab soal yang memerlukan penalaran (berpikir tingkat tinggi) masih belum tercapai secara memadai (hanya sekitar 5\%) (Kemdikbud, 2013:2). Oleh karena itu, capaian literasi anak perlu terus dilakukan pembinaan sebagai upaya menumbuhkan kompetensi dan performansinya melalui budaya membaca dan menulis. Selain itu, mengembangkan informasi dari apa yang dilihat, didengar, dan dipikirkan sehingga memungkinkan memunculkan ide-ide kritis-kreatif yang dapat meningkatkan kemampuan berpikir peserta didik.

Kemampuan literasi (berpikir) siswa yang rendah tidak dapat dimungkiri bahwa itu sebagai dampak dari model pembelajaran yang telah lalu yang dikelola semua bidang studi, termasuk bahasa Indonesia. Untuk itu, pengembangan kemahiran berbahasa Indonesia melalui kemampuan menulis teks perlu dilakukan. Pengembangan kemampuan menulis berbasis teks adalah salah satu upaya membina dan mengembangkan pola berpikir siswa secara cepat, runtut, kritis, dan kreatif. Pencapaian kompetensi menulis teks sesuai dengan kurikulum 2013 sudah dilaksanakan lama dan dari tingkatan pendidikan sekolah dasar. Pada tingkat ini, siswa telah dituntut untuk menulis kalimat dengan gagasan sederhana dalam urutan yang jelas dan menggunakan kata-kata sendiri. Selanjutnya, pada tingkat sekolah menengah siswa dituntut mengembangkan tulisan dalam wujud teks berdasarkan rambu-rambu komponen penilaian yang lebih lengkap, seperti penggunaan struktur teks, pengembangan tema atau topik dengan isi, penerapan pemilihan kata, penggunaan kalimat bergaya bahasa, dan komponen atau aspek mekanik seperti ejaan bahasa Indonesia. Selain itu, sesuai dengan standar kompetensi lulusan bidang studi bahasa Indonesia, bahwa orientasi menulis berkenaan dengan menulis efektif berbagai jenis teks dalam berbagai konteks dan tujuan untuk mencapai pembelajaran 
kemahiran berbahasa komunikatif (Bachman, 1990:85). Artinya, penguasaan unsur kebahasaan dalam menulis teks sebagai komponen penilaian tidak boleh diabaikan untuk mengembangkan kepekaan kontekstual yang serasi dan tinggi. Sebab, menulis yang sederhana sekalipun tidak mungkin dapat terwujud tanpa pengetahuan kaidah bahasa yang juga sederhana. Penguasaan kaidah kebahasaan ini penting untuk memunculkan gagasan dalam menulis teks termasuk wawasan lingkungan menulis teks cerita. Sebab, menulis teks cerita merupakan salah satu tuntutan keterampilan menulis (sebagai bagian literasi) di sekolah menengah (Wiratno, 2014).

Kompetensi menulis berbasis teks ini harus dimiliki mahasiswa calon guru bahasa Indonesia sejak mereka mempersiapkan diri di perkuliahan. Hal ini penting dimiliki sebagai penguat wawasan akademik dan pedagogi dalam pengelolaan pembelajaran agar ketika terjun mengajar di kelas telah siap. Dengan demikian, secara bertahap sinyalemen hasil pembelajaran menulis teks siswa yang masih jauh dari harapan, seperti kurang mampu menuangkan gagasan ke dalam tulisan dan lemah dalam mengembangkan tema ke dalam isi tulisan dapat diatasi. Cara praktis dan cepat dalam melatih menulis harus dimiliki mahasiswa calon guru bahasa Indonesia sehingga upaya tradisional yang selama ini diterima siswa di kelas dengan meminta menulis setelah penjelasan panjang lebar berakhir, yang berujung pada tugas rumah dapat diminimalisasi dengan langsung praktik menulis teks di kelas atau saat pembelajaran berlangsung yang didampingi guru. Proses pembelajaran yang diterima peserta didik menjadi lebih bermakna dan efektif. Proses menulis melalui penuangan ide dalam teks dapat dialami langsung oleh siswa dan dilakukan melalui pembimbingan guru bahasa Indonesia yang membelajarkan melalui sistem pemodelan yang tepat dalam 'membangun teks', baik membangun teks secara bersama maupun membangun teks secara mandiri. Pembelajaran yang dialami siswa dengan pendampingan guru langsung dan bukan melalui tugas rumah, hasilnya tentu akan berbeda, harapannya lebih berkualitas. Karena, pembelajaran keesokan harinya tentu tidak akan mengulang materi yang sudah lampau. Hal ini relevan dengan pengertian kemampuan menulis merupakan suatu kemahiran seseorang (peserta didik) dalam menuangkan gagasan menggunakan kolektivitas pengetahuan kebahasaan melalui pikiran yang direfleksikan dalam tulisan yang dapat diinformasikan kepada orang lain secara berhasil (Yulistio, 2012). Dalam hal ini, adanya guru bahasa Indonesia yang langsung mendampingi proses pembelajaran dapat berperan sebagai fasilitator sekaligus memantau proses pembelajaran menulis teks secara bersamasama dan mandiri hingga tercapai hasil yang baik.

Kegiatan menulis memang bukan hal mudah bagi mahasiswa bahasa Indonesia terlebih lagi bagi siswa yang tanpa pendampingan guru bahasa Indonesia di sekolah. Pada era sistem pembelajaran yang tidak harus tatap muka seperti pembelajaran secara daring (online) maka peran guru sebagai fasilitator sangat penting. Hal ini tentu sama pentingnya ketika pengelolaan pembelajaran dilakukan secara online, baik untuk penyampaian informasi melalui aplikasi virtual zoom, melalui WhatsApp, dan 
google classroom, serta aplikasi lain, maka keberadaan guru yang benar-benar berperan sebagai pengarah dan fasilitator proses pembelajaran sangat diperlukan. Kemampuan menulis peserta didik akan cepat menemukan bentuknya ketika guru sebagai pelatih mengarahkan secara baik. Pembelajaran kemampuan menulis termasuk menulis teks cerita akan cepat terwujud jika peserta didik banyak melakukan pelatihan menulis secara rutin.

Hasil pengamatan terhadap

aktivitas mahasiswa Prodi Pendidikan

Bahasa Indonesia FKIP Universitas

Bengkulu dalam berkarya ilmiah lebih banyak membuat tugas bidang kesastraan dan juga drama, baik melalui menulis maupun pementasan. Kegiatan menulis cenderung lebih cepat mengantarkan mahasiswa mencapai kesuksesan. Hanya saja, untuk menjadi penulis yang terampil dalam karya sastra terlebih dalam menulis karya ilmiah, perlu pelatihan menulis yang rutin dan memahami kaidah penulisan formal. Terus terang masih banyak mahasiswa yang belum memahami aturan dalam menulis, bahkan masih replikasi tulisan terdahulu. Artinya, untuk mewujudkan produk kemampuan menulis teks yang baik perlu dipahami kaidah/aturan menulis formal yang memperhatikan komponen penilaian menulis. Menurut beberapa guru, kesulitan utama terletak pada kegiatan menuangkan ide pokok atau gagasan ke dalam rangkaian kalimat yang runtut dan menjadi tulisan yang lengkap dan mudah dibaca. Tulisan siswa dimungkinkan kurang berkembang dengan baik karena ketika mulai menulis apa yang sudah dipikirkan mengalami kebuntuan. Hal ini terjadi karena siswa kurang mampu mengekspresikan gagasan dan keruntutan dalam berpikir. Hambatan muncul kembali ketika mulai menulis beberapa jenis teks dan beberapa guru tampak belum siap mengekspresikan proses pembelajaran menulis teks secara terampil dan profesional. Sebab, pengetahuan menulis teks ini baru diperoleh secara instan ketika mengikuti pelatihan kurikulum 2013, yang belum sepenuhnya dapat dipahami dan dikuasai melalui pendekatan teks bidang studi bahasa Indonesia. Kemampuan menulis teks memerlukan kecakapan dan kemahiran tersendiri bagi guru bahasa Indonesia. Berkaitan dengan kemampuan mahasiswa dalam mewujudkan tulisan, menulis teks narasi atau cerita lebih mudah dideskripsikan mahasiswa sebab menulis teks ini dapat dilakukan melalui rekaan peristiwa atau khayalan, yang dapat lahir dari proses berpikir rasional dan irasional tanpa melihat peristiwa dan kejadian nyata serta tidak terbatas waktu dan tempat.

Menulis teks cerita merupakan salah satu bagian dari tuntutan keterampilan menulis teks di sekolah menengah. Oleh karena itu, pemilikan kemahiran dalam menulis teks ini perlu diupayakan secara baik oleh mahasiswa calon guru bahasa Indonesia. Cerita atau narasi merupakan kisahan peristiwa atau kejadian, baik rekaan maupun kenyataan, sebagai wujud imajinasi lisan atau tulisan. Kemampuan menulis teks cerita adalah kemahiran atau kecakapan seseorang dalam menuangkan pesan melalui pengembangan gagasan, ide, dan pemikiran dalam bentuk kisah peristiwa, rekaan atau nyata melalui penggunaan bahasa tulis (Wiratno, 2014). Komponen kemampuan menulis teks cerita ini, meliputi rubrik penilaian (1) kesesuaian tema dengan isi, (2) struktur teks cerita meliputi orientasi, komplikasi, dan 
resolusi, (3) kesesuaian pilihan kata (diksi), (4) penggunaan kalimat bergaya bahasa cerita, dan (5) penguasaan mekanik (ejaan bahasa Indonesia dan tulisan tangan). Bukti kecakapan mahasiswa (calon guru) bahasa Indonesia dalam pembelajaran kemampuan menulis teks cerita akan berdampak pada perubahan pengetahuan, keterampilan, dan sikapnya. Untuk itu, pencapaian kemampuan menulis teks cerita mahasiswa Prodi Bahasa Indonesia perlu dilakukan melalui penelitian. Berdasarkan latar belakang di atas maka tujuan penelitian ini untuk mendeskripsikan kemampuan menulis teks cerita mahasiswa Program Sarjana Pendidikan Bahasa Indonesia FKIP Universitas Bengkulu.

\section{TINJAUAN PUSTAKA}

\section{Hakikat Kemampuan Menulis}

Kemampuan menulis merupakan kecakapan seseorang dalam merangkai bahasa dan keruntutan pikiran melalui tulisan. Menulis merupakan suatu hasil usaha seseorang dalam proses menuangkan buah pikiran ke dalam bahasa tulis melalui kalimat-kalimat yang dirangkai secara lengkap dan jelas sehingga dapat dikomunikasikan kepada pembaca secara berhasil. Rivers (dalam Hadley, 1993:290 -292) mengemukakan bahwa kemampuan menulis merupakan kecakapan seseorang dalam praktik menulis secara alamiah dengan memanfaatkan konteks nyata.

Secara khusus kemampuan menulis melibatkan dua hal, yakni kemampuan menerima dan menggunakan. Kemampuan yang terarkhir ini berkaitan dengan aktivitas yang menekankan pada penggunaan kode bahasa untuk tujuan mengomunikasikan gagasan, ide-ide dalam wujud tulisan. Byrne (dalam Yulistio,
2012:25) menyatakan bahwa keterampilan menulis adalah suatu hasil usaha seseorang dalam mewujudkan dan kolektivitas pengetahuan kebahasaan dan pengolahan gagasan melalui pikiran yang direfleksikan melalui wujud tulisan sehingga dapat dikomunikasikan kepada pembaca secara berhasil. Dengan demikian, dapat dikatakan bahwa kemampuan menulis adalah kecakapan penulis (guru dan siswa) dalam menyampaikan gagasan, ide-ide, atau pesan sebagai akumulasi pikiran dan pengalaman dengan menggunakan rangkaian lambang bahasa ke dalam wujud tulisan. Kemampuan menulis adalah kecakapan seseorang (guru) dalam menuangkan ide-ide, gagasan melalui pikiran yang tersusun logis dengan memanfaatkan kalimat-kalimat yang terangkai secara baik dan dituangkan menggunakan bahasa tulis. Tulisan berwujud teks maksudnya bahwa tulisan yang dihasilkan sebagai produk menulis seseorang yang terdiri dari berbagai jenis tulisan (berbagai jenis teks).

Kemampuan menulis teks ini tidak dapat datang begitu saja, tetapi memerlukan waktu dan kesempatan. Artinya, apabila ada waktu dan kesempatan yang dimiliki seseorang dapat diprogramkan untuk melakukan menulis teks tersebut. Menulis teks sebagai bagian dari keterampilan dalam berbahasa dapat dicapai melalui kegiatan berlatih secara rutin hingga tercapai pemilikan keterampilan dalam mewujudkan berbagai jenis teks tertulis. Berlatih menulis teks secara terprogram dengan rutinitas yang efektif-efisien dapat dilakukan seseorang (guru dan siswa) melalui pemahaman dan penerapan terhadap unsur bentuk (form) dan fungsi (function) struktur kebahasaan, alur berpikir logis dan runtut, dan struktur 
tulisan atau struktur teks yang akan ditulis sehingga mampu mengomunikasikan pesan, ide-ide, atau gagasan kepada pembaca secara berhasil.

Kemampuan menulis teks dalam proses pembelajaran bahasa Indonesia kurikulum 2013 dipelajari di sekolah menengah. Menulis teks dimaksudkan agar peserta didik mendapatkan pengetahuan dan keterampilan serta sikap dalam menulis teks bahasa Indonesia secara baik dan benar. Teks yang ditulis haruslah merupakan satuan bahasa yang memiliki kandungan makna, pikiran, dan gagasan yang lengkap. Hal inilah yang menjadi dasar dalam mencapai materi pembelajaran menulis. Artinya, materi pembelajaran menulis, tidak cukup hanya berupa menulis paragraf dengan menggunakan kalimat utama dan kalimat penjelas serta menemukan tema dan ide pokok paragraf saja, tetapi harus sesuai dengan jenis teks yang dikembangkan. Satuan bahasa dengan kandungan makna, pikiran, dan gagasan yang lengkap tidak lain adalah teks maka pembelajaran bahasa Indonesia sudah selayaknya menerapkan pendekatan teks dengan capaian proses dan hasil pada penguasaan penggunaan bahasa tulis, yakni menulis teks dengan berbagai ragam jenisnya.

Pendekatan Menulis dan Pembelajaran Menulis Teks

Pendekatan teks dalam menulis teks dengan latar belakang atau objek tulisan nyata akan memungkin penulis dapat mengaplikasikan peristiwa kehidupan yang sebenarnya. Blanchard (dalam Nur, 2001) menyatakan bahwa pembelajaran (termasuk menulis teks) dengan pendekatan kontekstual akan memungkinkan proses dan hasil pembelajaran terjadi dari hubungan yang erat dengan kehidupan sesungguhnya. Latief (2002) menegaskan bahwa pembelajaran menulis teks dengan pendekatan kontekstual akan membantu guru dan siswa mengaitkan isi materi pelajaran dengan dunia nyata. Menulis teks sesuai jenisnya harus mengacu pada konteks dan melibatkan peristiwa atau kejadian (nyata atau khayalan) sehingga menghasilkan wujud tulisan yang lebih realistis walaupun dalam jenis tertentu, seperti teks prosa fiksi juga dapat ditulis dari hasil bernarasi atau berimajinasi. Oleh karena itu, dalam menulis teks lebih tepat bersinergi dengan pendekatan kontekstual.

Menurut Johnson (2002), pembelajaran menulis teks secara kontekstual akan membantu guru dan siswa untuk dapat menemukan makna pelajaran dan kemampuan mengingat, tidak terkecuali apa jenis teksnya. Lebih lanjut, Johnson (2002) menegaskan bahwa komponen pembelajaran kontekstual mencakup delapan hal, yakni (1) pembuatan koneksi yang bermakna (making meaningful connections), (2) melakukan signifikansi pekerjaan (doing signifficant work), (3) belajar untuk mandiri (self regulated learning), (4) bekerja sama (collaborating), (5) berpikir kritis dan kreatif (critical and cerative thinking), mengutamakan kebutuhan individual (nurturing the individual), (7) pencapaian standar tinggi (reaching high standards), dan (8) penggunaan penilaian autentik (using authentic assessment). Ketika guru dan siswa menemukan makna di dalam pelajaran maka mereka akan melaksanakan proses pembelajaran dengan berliterasi dan mengingat apa yang mereka pelajari. Melalui teks yang disusun akan teraplikasikan hubungan yang jelas antara 
isi pelajaran, struktur teks, dan komponen pembangun teks dengan konteks kehidupan keseharian mereka sebagai suatu pengalaman baru yang bermakna.

Aktivitas yang dibagun melalui proses pembelajaran bahasa Indonesia antara guru dan siswa secara bersama-sama dan mandiri akan merupakan pengalaman pengetahuan yang bermakna. Dalam pembelajaran, peserta didik terlibat langsung dan berperan aktif dalam menemukan materi yang dipelajari sesuai dengan kenyataan serta dapat menerapkan kembali hasil pembelajaran dalam kehidupan yang sebenarnya. Dengan kata lain, bahwa ketika proses pembelajaran menulis teks sudah dilaksanakan maka personal pembelajaran, guru dan siswa, akan dapat mengaktifkan dan memperoleh pengalaman baru, mampu mempraktikkan pengalaman tersebut sebagai wujud keterampilan, dan mampu merefleksi hasil pembelajaran yang telah dicapai sebagai wujud implentasi sikap dalam berbahasa tulis (menulis teks) secara baik. Artinya, pembelajaran menulis teks siswa tidak serta-merta dapat diperoleh tanpa aktivitas nyata dalam belajar bersama-sama atau mandiri dan adanya peranan guru sebagai pengarah yang sukses.

Jenis Pembelajaran Menulis Teks di Sekolah

Bahan dan kegiatan proses pembelajaran menulis teks di sekolah menengah berdasarkan kurikulum 2013 sangat bervariasi dengan jenis materi yang beragam untuk tiap tingkatan kelas dan pendidikan. Khusus menulis teks cerita merupakan salah satu jenis menulis teks yang ada di kelas VII SMP. Jenis lain yang ada di kelas tersebut, yakni teks tanggapan deskripsi, teks eksposisi, teks eksplanasi, dan teks cerita pendek. Kelima jenis teks tersebut secara metodologis dapat diwujudkan melalui kegiatan yang terencana dan terprogram dengan mengaktifkan siswa melalui empat langkah kegiatan dalam berbahasa, yakni (a) membangun konteks, (b) pemodelan teks, (c) kerja sama membangun teks, dan (d) kerja mandiri membangun teks (Wiratno, 2014).

Beberapa jenis teks dapat dibedakan atas dasar tujuan (yang tidak lain yakni fungsi sosial teks), struktur teks (tata organisasi), dan ciri kebahasaan teks tersebut. Sesuai dengan prinsip itu, suatu teks yang berbeda tentu memiliki fungsi yang berbeda, struktur teks berbeda, dan ciri kebahasaan yang berbeda pula. Dengan kata lain, bahwa pembelajaran bahasa Indonesia yang berbasis teks merupakan model pembelajaran yang memungkinkan pembelajar (siswa atau mahasiswa) dapat menguasai dan menggunakan berbagai jenis teks tersebut di masyarakat.

\section{Hakikat Cerita dan Struktur Teks Cerita}

Cerita adalah suatu kisah peristiwa kejadian, baik secara rekaan atau kenyataan, sebagai hasil berimajinasi seseorang. Dalam proses pembelajaran teks cerita dapat diwujudkan melalui keterampilan menulis, sedangkan menyampaikan cerita secara lisan merupakan keterampilan berbicara. Cerita merupakan kemampuan pragmatis seseorang yang dituangkan secara tertulis (Nurgiyantoro, 2001). Teks cerita mempunyai fungsi sosial untuk membuat deskripsi mengenai sesuatu, seperti dalam bentuk pengisahan. Dengan pengisahan disampaikan suatu peristiwa kejadian masa 
lalu dalam bentuk imajinasi dari peristiwa rekaan.

Berkaitan dengan komponen organisasi tulisan atau struktur teks, teks merupakan satuan bahasa terlengkap dengan kandungan makna, pikiran, dan gagasan. Dalam pengelompokkannya, teks dapat berwujud teks tulis dan teks lisan. Dalam menulis teks diperlukan organisasi atau struktur teks tersebut. Struktur teks yang baik akan membentuk pola berpikir yang baik pula sehingga setiap penguasaan jenis teks tertentu akan memiliki keruntutan kemampuan berpikir sesuai dengan jenis teks yang ditulis (Kemdikbud, 2013). Pada mahasiswa Prodi Pendidikan Bahasa dan Sastra Indonesia tentu saja keterampilan menulis merupakan tuntutan wajib sebagai suatu kompetensi capaian. Terlebih lagi bagi mahasiswa calon guru bahasa Indonesia yang telah memiliki bekal keterampilan menulis dasar dan menulis kreatif maka kompetensi menulis harus segera diwujudkan dalam implementasi seperti dalam wujud tulisan. Untuk itu, mahasiswa sebagai calon guru bahasa Indonesia harus lebih dahulu mengetahui jenis-jenis teks atau tulisan tersebut. Hal ini sangat penting dikuasai karena mahasiswa dalam perkuliahan tidak terlepas dari tugas membuat teks (menulis), salah satu jenisnya yakni menulis teks cerita.

Kemdikbud (2014) dan Wiratno (2014) mendeskripsikan beberapa jenis teks atas struktur teksnya yang berbedabeda sesuai kedalaman bentuk dan fungsinya. Jenis teks cerita, dengan unsur struktur teks mencakup (a) orientasi cerita, (b) urutan peristiwa atau komplikasi cerita, dan (c) reorientasi atau resolusi cerita, serta (d) koda. Struktur teks cerita ini menjadi dasar penilaian, sebagai salah satu komponen dalam menulis teks cerita dengan bobot tertentu. Dalam membangun teks yang perlu dipahami bahwa struktur teks cerita unsur orientasi cerita merupakan bagian pembuka tulisan yang bersifat umum, unsur urutan peristiwa merupakan bagian pengembangan isi atau penceritaan, dan unsur reorientasi resolusi merupakan bagian penyelesaian peristiwa cerita, dan koda merupakan bagian akhir atau penutup cerita sebagai bentuk pengulangan.

\section{Penilaian Kemampuan Menulis Teks Cerita}

Komponen dalam menilai kualitas tulisan dapat dilakukan dengan berbagai prosedur. Perkins (dalam Hadley) mengemukakan prosedur yang dapat digunakan untuk menilai tulisan mencakup (1) penilaian holistik, yakni prosedur penilaian tulisan yang digunakan untuk menilai kecakapan secara menyeluruh dan langsung pada tulisan dengan menekankan pada sistem komunikasinya, (2) penilaian analitik adalah prosedur menilai tulisan secara terpisah-pisah berdasarkan komponen menulis yang dirujuk, (3) penilaian primer adalah prosedur dalam menilai tulisan menurut unsur atau ciri-ciri dasar suatu tulisan, seperti aspek organisasi, kosakata, dan komponen strukturnya. Heaton mengemukakan bahwa penilaian tulisan lebih baik dilakukan melalui penilaian analitik dengan jumlah penilai lebih dari satu. Hal ini dimaksudkan untuk mendapatkan hasil penilaian yang lebih objektif. Dengan menggunakan penilaian secara analitik berarti hasil menulis siswa akan dinilai menurut komponen menulis yang telah ditentukan.

Model penilaian menulis teks secara analitik menurut Jacobs dkk 
(1981:30 - 31) mencakup lima komponen, yakni (1) kesesuaian tema dengan isi, (2) struktur teks, (3) ketepatan pilihan kata, (4) penggunaan kalimat bergaya bahasa cerita, dan (5) mekanik (ejaan dan tulisan tangan).

Bobot skor masing-masing komponen bervariasi, seperti kesesuaian tema dengan isi bobot skor 25, struktur teks bobot skor 20 , pilihan kata bobot skor 20, penggunaan kalimat bobot skor 25, dan mekanik bobot skor 10 sehingga total nilai kelima komponen sebesar 100. Skor semua komponen adalah skor total menulis teks. Dalam penelitian ini, rubrik penilaian kemampuan menulis teks menggunakan pola analitik dengan modifikasi pada komponen organisasi atau struktur teks. Artinya, penilaian yang dilakukan dimaksudkan untuk mendapatkan hasil menulis yang lebih objektif dan rinci terhadap komponen kemampuan menulis teks sebagai hasil pembelajaran menulis. Oleh karena itu, penilaian menulis teks cerita ini dilakukan secara analitik dan didasarkan pada komponen kesesuaian tema dengan isi, ketepatan struktur teks cerita, ketepatan pilihan kata, ketepatan penggunaan kalimat bergaya bahasa cerita, dan mekanik (ejaan dan tulisan tangan).

\section{METODE PENELITIAN}

Penelitian ini menggunakan pendekatan kuantitatif dan metode deskriptif. Secara kuantitatif bahwa penelitian ini menggunakan fakta berupa angka-angka dalam analisisnya. Metode deskriptif digunakan untuk mendata kemampuan menulis teks cerita mahasiswa Prodi Pendidikan Bahasa Indonesia FKIP Universitas Bengkulu. Tempat penelitian di Jalan W.R. Supratman, Kandang Limun, Bengkulu, Gedung Kuliah Bersama (GKBIV). Waktu penelitian, Kamis, 6 September 2018, Pukul 16.20 s.d. 18.00 WIB. Dari populasi seluruh mahasiswa Prodi Pendidikan Bahasa Indonesia FKIP Universitas Bengkulu semester ganjil 2018/2019 diambil sampel secara purposive, mahasiswa kelas III-A sebanyak 34 orang. Data penelitian adalah tulisan mahasiswa berupa teks cerita dengan tema "kasih sayang", sebanyak 34 judul. Pengumpulan data menggunakan teknik tes dengan instrumen berupa petunjuk menulis teks cerita dan pedoman penilaian kemampuan menulis teks cerita, mencakup aspek (a) kesesuaian topik dengan isi, (b) struktur teks meliputi unsur orientsi, komplikasi, resolusi, dan koda, (c) pilihan kata, (d) penggunaan kalimat, dan (e) mekanik (ejaan dan tulisan tangan). Analisis data menggunakan statistik deskriptif untuk menentukan nilai rerata dan persentase dan selanjutnya dikonfirmasi secara kualitatif (Djiwandono, 2008).

Deskripsi kemampuan menulis teks cerita mahasiswa Prodi Pendidikan Bahasa Indonesia FKIP Universitas Bengkulu dengan tema "kasih sayang" dan topiknya "kasih sayang kepada orang tua" dapat digambarkan sebagaimana data hasil penelitian berikut ini. 
Tabel 1. Kemampuan Mahasiswa

\begin{tabular}{|l|l|l|l|l|l|}
\hline No & Aspek & Skor Total & Rerata & $(\boldsymbol{\%})$ & Kategori \\
\hline 1 & Kesesuaian isi & 644 & 18,94 & 20,5 & Baik \\
\hline 2 & Stuktur teks & 547 & 16,09 & 21,7 & Baik \\
\hline 3 & Pilihan kata & 489 & 14,38 & 19,4 & Baik \\
\hline 4 & Kalimat bergaya bahasa cerita & 586 & 17,24 & 18,6 & Baik \\
\hline 5 & Mekanik; ejaan dan tulisan tangan & 249 & 7,32 & 19,8 & Baik \\
\hline & Sumber data 34 orang & 2515 & $\mathbf{7 3 , 9 7}$ & 100 & Baik \\
\hline
\end{tabular}

Berdasarkan data di atas, dari 34 orang mahasiswa yang mengikuti tes kemampuan menulis teks cerita diperoleh hasil baik dengan skor 73,97. Pencapaian kemampuan menulis teks cerita ini didasarkan pada lima aspek penilaian, mencakup isi, struktur teks, pilihan kata, kalimat naratif, dan mekanik. Hasil ini bermakna bahwa kelima aspek menulis cerita sudah dikuasai secara baik. Namun, capaian kemampuan menulis ini masih perlu diperbaiki, dipertahankan, dan ditingkatkan hingga menjadi lebih baik

Pencapaian kemampuan menulis teks cerita mahasiswa ini berdampak pada persentase sumbangan setiap aspek yang juga merata. Sumbangan terbesar diperoleh aspek struktur tes cerita sebesar $21,7 \%$. Hal ini berarti bahwa dalam menuangkan isi cerita mahasiswa sudah menggunakan struktur yang benar, seperti unsur orientasi, komplikasi, dan resolusi. Selanjutnya, aspek kesesuaian tema dengan isi memberikan sumbangan $20,5 \%$ yang berarti isi telah diuraikan sesuai tema walaupun belum mendetail, aspek ketepatan pilihan kata memberikan sumbangan $19,4 \%$ juga menunjukkan bahwa naskah cerita telah disusun dengan diksi yang relevan, dan penggunaan kalimat dengan sumbangan sebesar 18,6\% juga sudah mendeskripsikan isi sesuai gaya bahasa cerita, serta aspek mekanik (ejaan dan tulisan tangan) memberikan sumbangan $19,8 \%$ yang tentu sudah dikembangkan menggunakan bahasa yang baik dan benar. Kemudian, persentase sumbangan setiap aspek tersebut dapat dilihat pada deskripsi diagram batang berikut ini.

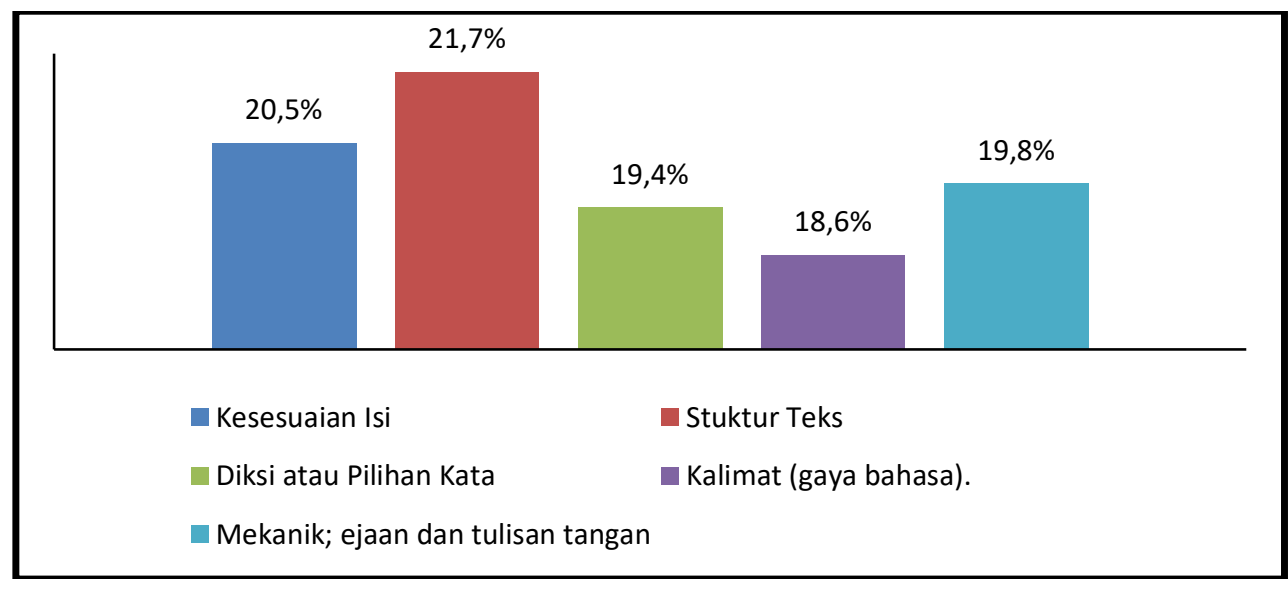

Selanjutnya, dari deskripsi bahwa dari 34 orang, sebanyak 7 orang frekuensi pilihan mahasiswa dalam berkategori sangat baik $(20,59 \%)$ mencapai kemampuan menulis teks cerita kemampuan menulis ceritanya, sebanyak 
17 orang termasuk berkategori baik (50\%), dan selebihnya sebanyak 10 orang berkategori cukup (29,41\%). Berdasarkan frekuensi di atas dapat dideskripsikan pada diagram batang berikut ini.

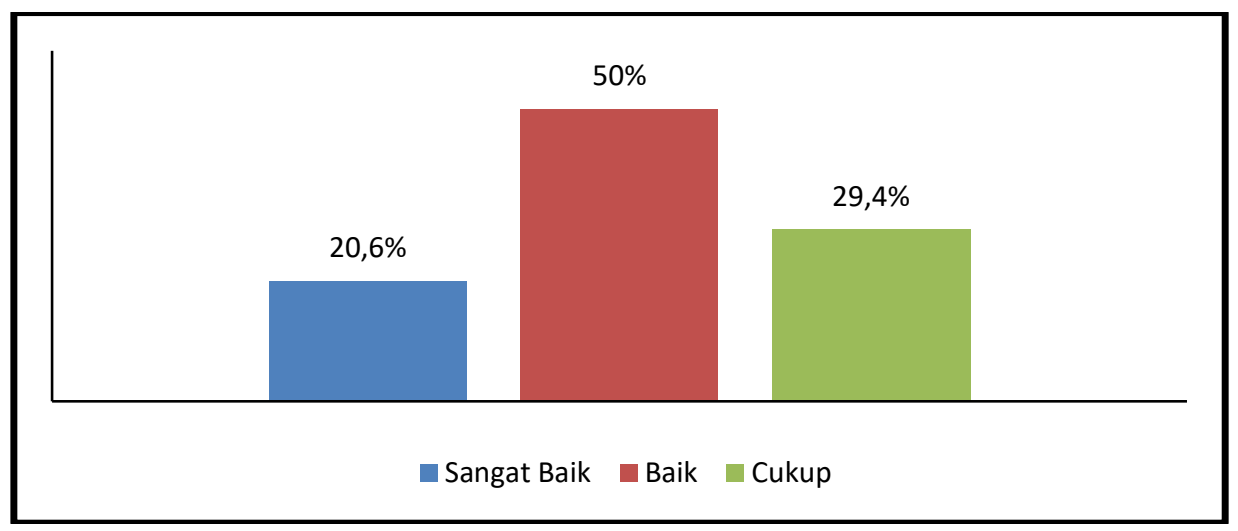

Capaian di atas menunjukkan bahwa kemampuan menulis teks cerita mahasiswa Prodi Pendidikan Bahasa Indonesia FKIP Universitas Bengkulu yang didasarkan pada lima aspek tersebut sudah dikuasai secara baik walaupun belum maksimal. Hal ini terlihat dari penguasaan yang telah dicapai mahasiswa mayoritas berkategori baik. Artinya, secara umum kemampuan menulis cerita mahasiswa sudah baik, bahkan terdapat 7 orang sudah sangat menguasai dalam menulis cerita. Terhadap 10 orang yang masih berkategori cukup ini perlu dilakukan perbaikan melalui pembelajaran menulis teks, seperti melalui pelatihan terprogram untuk meningkatkan capaian kemampuan menulis teks ceritanya.

$$
\text { Secara khusus, capaian }
$$

kemampuan menulis teks cerita mahasiswa Prodi Pendidikan Bahasa Indonesia FKIP Universitas Bengkulu dalam setiap komponen/aspeknya dapat dilihat pada deskripsi berikut ini.

\section{Capaian Aspek Kesesuaian Tema dengan Isi}

Pada capaian aspek relevansi tema dengan isi cerita bahwa mahasiswa telah mengembangkan isi tulisan terhadap tema "kasih sayang" atau topik "berbakti kepada orang tua" dengan kualitas baik atau memperoleh rerata skor sebesar 18,94. Artinya, mahasiswa telah menulis isi teks relevan dengan tema yang diberikan dan memerlukan sedikit uraian yang lebih lengkap untuk mencapai hasil sangat baik. Berdasarkan persentase frekuensi pemilih dari 34 orang mahasiswa, (a) sebanyak 11 orang mendapat skor berkategori sangat baik $(32,4 \%)$, (b) sebanyak 22 orang mendapatkan skor berkategori baik $(64,7 \%)$, dan (c) sebanyak 1 orang mendapat skor berkategori cukup (2,9\%). Hal ini menunjukkan bahwa pengembangan aspek isi sudah lebih baik dibandingan dengan deskripsi capaian frekuensi secara umum sebab hanya menyisakan satu orang yang belum berkemampuan baik. Capaian besar persentase frekuensi tersebut dapat digambarkan dalam diagram batang berikut ini. 


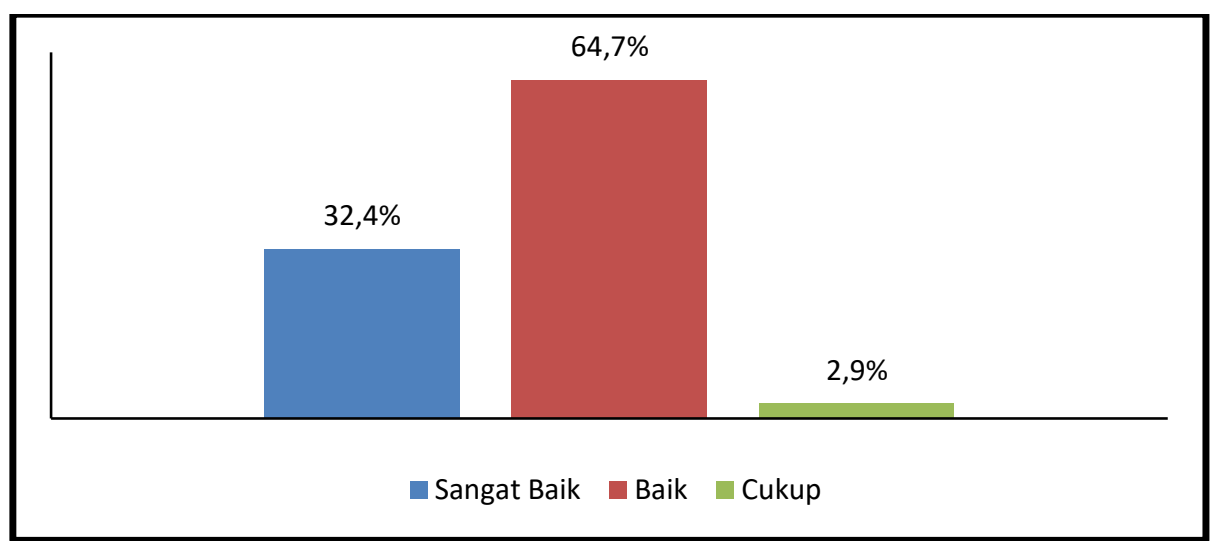

\section{Capaian Aspek Struktur Teks Cerita}

Pada capaian aspek struktur cerita yang meliputi orientasi, komplikasi, dan resolusi, mahasiswa telah menyusun urutan struktur cerita dengan hasil baik atau memperoleh rerata skor sebesar 16,09. Artinya, pada aspek struktur ini penguasaan mahasiswa sudah baik, tetapi belum berada pada kualitas terbaik. Berdasarkan persentase frekuensi pemilih dari 34 orang mahasiswa, bahwa (a) sebanyak 15 orang mendapat skor berkategori sangat baik $(44,1 \%)$, (b) sebanyak 17 orang mendapatkan skor berkategori baik (50\%), dan (c) sebanyak 2 orang mendapatkan skor cukup (5,9\%). Hal tersebut menunjukkan bahwa sebaran mahasiswa dalam kemampuan menulis struktur teks cerita sudah mencapai hasil yang lebih baik dan perlu perubahan dalam pengembangan unsur teksnya agar mengubah capaian pada dua mahasiswa yang masih berkemampuan cukup dalam aspek struktur ini. Capaian besar persentase frekuensi aspek struktur dapat dilihat dalam diagram batang berikut ini.

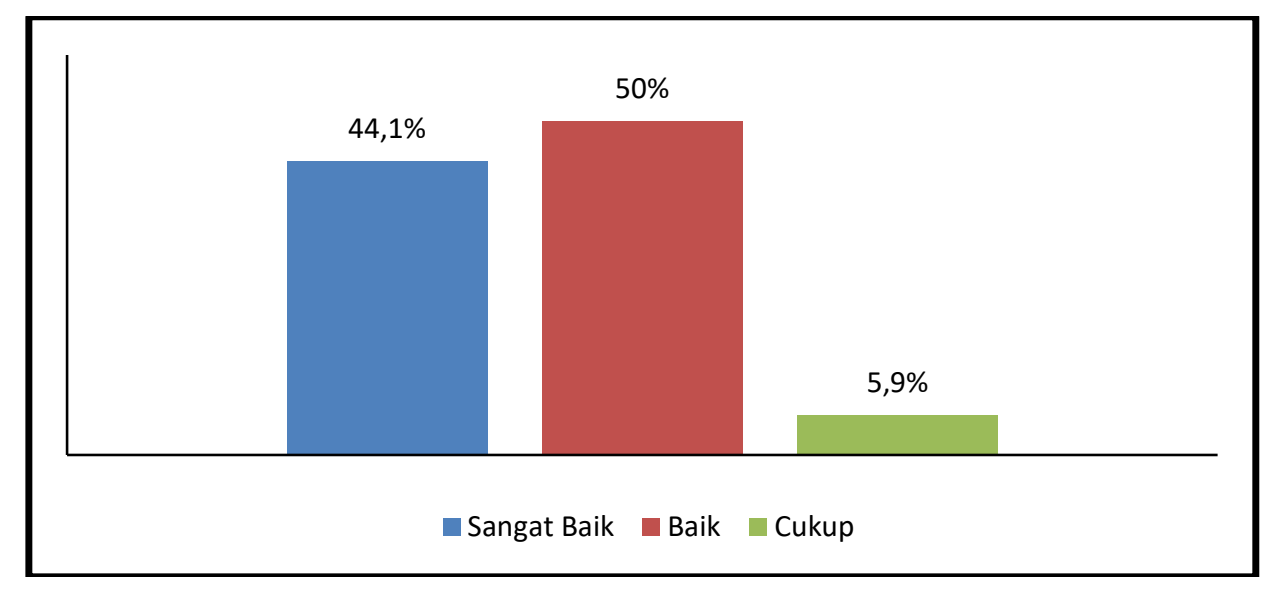

Capaian Aspek Ketepatan Pilihan Kata (Diksi)

Pada capaian aspek pilihan kata dalam menulis teks cerita yang berkaitan dengan kata khusus tema 'kasih sayang' mendapatkan skor rata-rata sebesar 14,38 berkategori baik. Artinya, pada aspek ini penguasaan mahasiswa sudah berada pada kualitas baik walaupun belum maksimal. Berdasarkan perolehan persentase frekuensi pilihan kata dengan pemilih 34 orang mahasiswa, bahwa (a) sebanyak 3 orang mendapat skor sangat baik $(8,8 \%)$, (b) sebanyak 27 orang mendapatkan skor 
baik $(79,4 \%)$, dan (c) sebanyak 4 orang mendapatkan skor kategori cukup (11.8\%). Capaian aspek diksi atau pilihan kata dalam menulis cerita mahasiswa perlu terus ditingkatkan hingga mencapai skor maksimal tertinggi sebesar 20. Capaian persentase frekuensi aspek diksi dapat dilihat dalam diagram batang berikut ini.

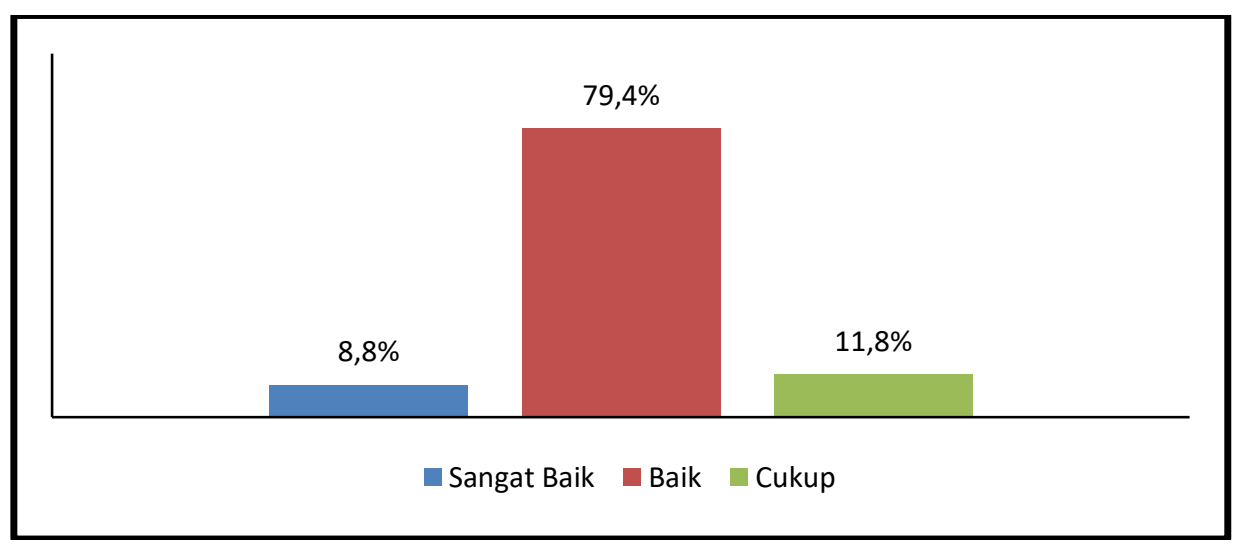

Capaian Aspek Kalimat bergaya Bahasa Cerita

Pada deskripsi hasil penilaian aspek penggunaan kalimat bergaya bahasa cerita mencapai skor rata-rata sebesar 17,24 berkategori baik. Artinya, pada aspek penggunaan kalimat bergaya bahasa cerita ini, penguasaan mahasiswa sudah berhasil baik walaupun belum maksimal karena belum mencapai skor 25. Secara spesifik capaian perolehan persentase frekuensi penggunaan kalimat dengan pemilih 34 orang mahasiswa, bahwa (a) sebanyak 19 orang $(55,9 \%)$ berkategori sangat baik dan (b) sebanyak 15 orang $(44,1 \%)$ berkategori baik, sedangkan selebihnya tidak ada. Perolehan besar persentase frekuensi aspek kalimat ini secara lengkap dapat dilihat dalam diagram batang berikut ini.

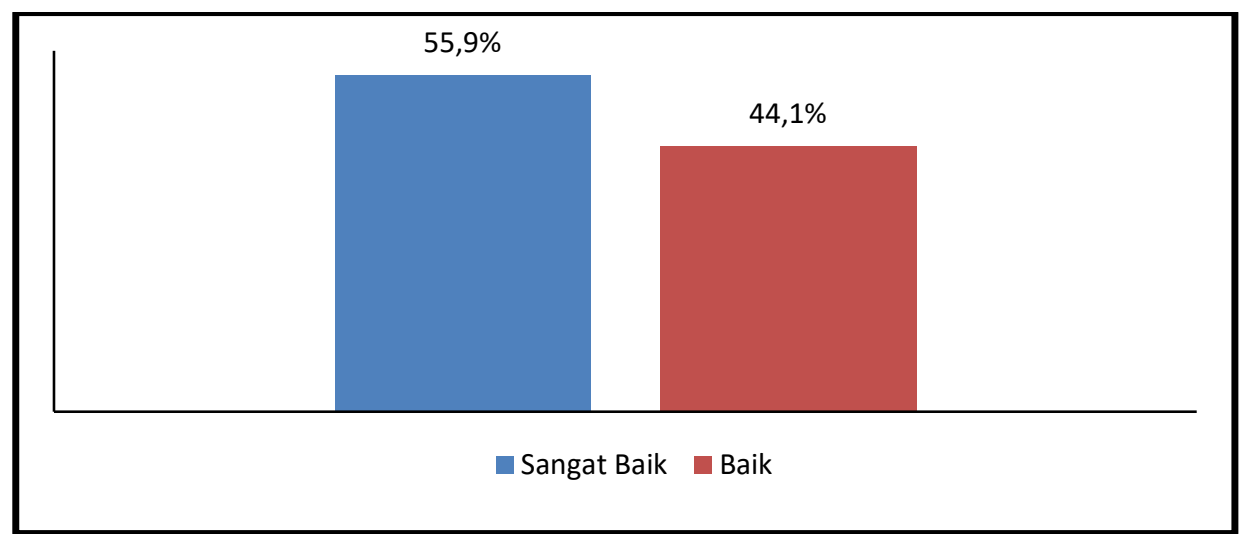

Capaian Aspek Mekanik (Ejaan Bahasa Indonesia)

Berdasarkan capaian aspek mekanik yang berkaitan dengan penggunaan ejaan bahasa Indonesia dan tulisan tangan diperoleh skor rata-rata sebesar 7,32 berkategori baik. Penerapan ejaan bahasa Indonesia dalam teks sudah baik, hanya belum mencapai skor tertinggi sebesar 10 sehingga perlu upaya untuk 
meningkatkan aspek ini agar lebih baik. Berdasarkan perolehan persentase frekuensi pemilihan dari 34 orang, bahwa terdapat (a) sebanyak 2 orang $(5,9 \%)$ termasuk dalam kategori sangat baik, (b) sebanyak 30 orang $(88,2 \%)$ termasuk dalam kategori baik, dan (c) sebanyak 2 orang $(5,9 \%)$ termasuk dalam kategori cukup. Gambaran hasil persentase frekuensi aspek mekanik ini dapat dilihat dalam diagram batang berikut ini.

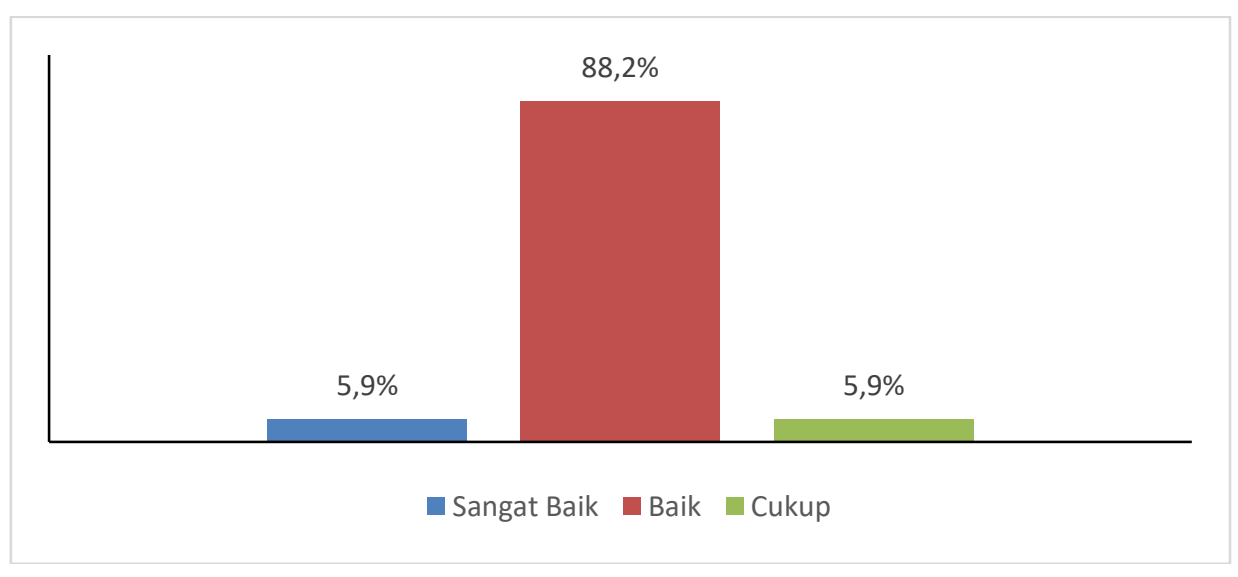

\section{Pembahasan}

Berdasarkan hasil penelitian bahwa kemampuan menulis teks cerita mahasiswa berkategori baik $(73,97)$. Pencapaian hasil tersebut didasarkan pada kelima aspek penilaian analitik yang semuannya berkategori baik, yakni (1) kesesuaian tema dengan isi $(18,94)$ memberikan sumbangan $20,5 \%$, (b) struktur cerita $(16,09)$ memberikan sumbangan $21,7 \%$, (c) diksi atau pilihan kata $(14,38)$ memberikan sumbangan 19,4\%, (d) kalimat bergaya bahasa cerita $(17,24)$ memberikan sumbangan $18,6 \%$, dan aspek (e) mekanik $(7,32)$ memberikan sumbangan 19,8\% dengan sumbangan tertinggi dicapai aspek struktur cerita.

Hasil ini menunjukkan bahwa mahasiswa semester III-A Prodi Pendidikan Bahasa Indonesia FKIP Universitas Bengkulu, tahun 2018/2019 sudah memiliki kualitas yang memadai dalam menulis teks cerita. Hal ini sesuai dengan pendapat Rivers (dalam Hadley, 1993) yang mengemukakan bahwa kemampuan menulis merupakan kecakapan seseorang dalam menggunakan unsur kebahasaan dan organisasi tulisan sesuai konteks. Artinya, sesuai dengan hasil capaian setiap aspek, bahwa mahasiswa sudah dapat mengembangkan gagasan tulisan (tema) yang dikembangkan menjadi judul dan isi tulisan dalam rangkaian paragraf atau teks cerita yang bermakna. Hanya saja, karena capaian tersebut belum maksimal maka masih perlu terus dikembangkan bahkan pada semua aspek, yakni pengembangan isi, struktur, diksi, penggunaan kalimat, dan mekanik (ejaan dan tulisan tangan) agar lebih baik lagi. Hal ini sesuai dengan pemikiran Wiratno (2014) bahwa mahasiswa perlu dilatih terus-menurus dalam mewujudkan tulisan yang lebih baik dengan menulis teks secara terprogram melalui membangun konteks, pemodelan teks, kerja sama membangun teks, dan kerja mandiri dalam mewujudkan teks yang baik hingga memiliki kecakapan dalam 
mengembangkan teks secara mandiri dan berkarakter.

Pada pencapaian kemampuan menulis cerita setiap aspek perlu dibenahi proses pembelajarannya dengan penekanan pada unsur-unsur tertentu agar lebih bermakna dan mengembangkan kebutuhan setiap komponennya. Pada aspek relevansi tema dengan pengembangan isi, mahasiswa sudah mencapai hasil baik, tetapi belum mencapai nilai sangat baik. Aspek isi memerlukan pelatihan rutin dalam kepekaan memahami penjabaran tema menjadi judul dan isi tulisan yang lengkap dan akurat. Mahasiswa sebenarnya sudah mampu menguraikan dan mengembangkan tema "kasih sayang kepada orang tua" menjadi judul yang baik dan mengembangkannya menjadi isi tulisan cerita yang menarik dan memiliki kandungan pesan yang komunikatif. Walaupun capaian aspek ini belum mencapai skor maksimal. Hal ini sesuai dengan pendapat Byrne (dalam Yulistio, 2012), bahwa kemampuan menulis merupakan upaya seseorang dalam mewujudkan dan kolektivitas pengetahuan kebahasaan dan pengolahan gagasan (ideide) melalui pikiran menjadi kalimat-kalimat bermakna (mengembangkan topik menjadi isi tulisan) dalam suatu paragraf yang direfleksikan dalam naskah secara runtut, bergaya naratif, dan bernalar.

Begitu pula pada aspek struktur teks yang mengembangkan unsur orientasi, komplikasi, dan resolusi sudah diwujudkan oleh mahasiswa secara baik. Ketiga unsur pengembangan struktur cerita sudah tampak membedakan dari isinya. Pada bagian awal cerita yang dimulai dengan orientasi mahasiswa secara spesifik sudah menyampaikan pesan, gambaran isi, wawasan yang akan diceritakan. Namun, pada unsur komplikasi masih perlu pengembangan bagaimana memulai alur yang jelas dari mulai memunculkan masalah, terjadi tikaian cerita, dan mengakhiri konflik. Sementara itu, pada unsur resolusi cenderung belum maksimal khususnya dalam mengakhiri isi cerita bahkan masih ditemukan cerita yang tidak diakhiri dengan bagian resolusi yang tepat karena akhir komplikasi dirasakan penulisnya sebagai akhir cerita. Bagian resolusi ini perlu disusun dengan uraian yang lebih jelas, lebih spesifik, dan lebih menonjolkan gagasan penyelesaian akhir permasalahan yang jelas dan bahkan menarik. Hal ini sebagaimana penegasan dalam Kemdikbud (2013), bahwa penempatan struktur cerita yang baik akan membentuk struktur atau pola berpikir yang baik dan berurutan sehingga setiap pengembangan unsur struktur cerita akan tampak keruntutan berpikir yang jelas dari isi cerita yang ditulisnya.

Pada pencapaian kemampuan menulis teks cerita aspek diksi atau pilihan kata, mahasiswa sudah mendapatkan kualitas yang baik. Hanya saja perlu penguatan dalam hal pemilihan kata yang sesuai dengan tema dalam uraian isi. Kesalahan pilihan kata masih terjadi pada penjabaran tema dan judul tulisan serta uraian isi yang menggunakan diksi tidak relevan. Pilihan kata yang tidak tepat atau tidak rasional bahkan bernuansa tidak mendidik terlihat pada kata-kata dalam uraian isi, seperti kalimat seorang ibu yang bertanya kepada anaknya yang masih kecil berusia sekolah dasar, "mengapa kamu tak mau sekolah nak?" dan jawaban si anak "saya mau membantu ibu saja." Hal tersebut bukan pengembangan isi dan pilihan kata-kata yang baik. Sebab, jika seorang anak akan membantu orang 
tuannya bukan saat itu, tetapi ketika sudah mampu (dewasa) nanti dan sesuai karakter anak, dia belum saatnya untuk bekerja membantu orang tua, tetapi sesuai nalar ketika masih anak-anak harus belajar atau sekolah bukan bekerja apalagi dipekerjakan. Karena, dengan belajar yang berhasil nanti akan mendapatkan pengalaman untuk bekerja secara baik ketika sudah dewasa sebagai bentuk makna tersirat 'menopang ekonomi keluarga' untuk membantu orang tua. Di samping itu, banyak pilihan kata yang tidak relevan dengan tema, seperti kata-kata 'ibu yang sudah tua telah diambil nyawanya oleh yang maha kuasa' perlu diganti dengan kata "ibu yang dalam kondisi sakit-sakitan itu telah tiada atau meninggal dunia." Pemilihan kata mubazir juga masih terjadi, seperti penggunaan kata "jalan raya besar" di depan rumahku. Seharunya, digunakan diksi "jalan raya" atau "jalan besar" saja.

Pada penggunaan kalimat bergaya bahasa cerita, mahasiswa cenderung masih menggunakan beberapa kalimat tidak efektif sehingga kalimat yang digunakan semestinya bergaya bahasa cerita, tetapi justru bergaya formal seperti teks pidato. Contoh kalimat pembuka teks yang bergaya formal dan tidak menunjukkan kesan bergaya bahasa cerita menarik bagi pembaca, misalnya dari judul "Kasih Sayang Ibu kepada Anaknya" pada kalimat pertama paragraf orientasi, yakni "Pada suatu hari ada keluarga yang cukup harmonis dan penuh kasih sayang" sebaiknya dibuat bernilai deskripsi atau naratif sehingga bergaya bahasa cerita. Dari segi makna, kalimat tersebut kurang tepat sebab setiap hari tentu banyak keluarga harmonis seperti itu. Oleh karena itu, perlu diperindah misalnya menjadi "Pada suatu kampung terdapat sepasang suami-istri yang hidup sangat harmonis dan penuh kasih sayang serta berkecukupan." Kalimat tersebut akan menarik pembaca untuk menelusuri isi ceritanya ketika mulai membaca, tentu disertai pertanyaan di hati ada apa, dan mengapa dengan keluarga dalam cerita ini? Perlu wawasan mengembangkan struktur orientasi cerita yang menarik dan memancing minat orang untuk meneruskan membaca satu demi satu uraian isinya.

Pada pencapaian aspek mekanik khususnya penggunaan ejaan bahasa Indonesia masih terjadi kesalahan walaupun tidak fatal. Penulisan tanda baca (tanda hubung /-/) pada kata ulang ditulis dengan menggunakan spasi atau jarak, padahal seharusnya ditulis melekat. Misalnya, ditemukan penulisan "binatang - binatang", seharusnya ditulis "binatangbinatang." Penulisan kata "namun" di awal kalimat seharusnya disertai tanda baca koma /,/ atau ditulis "Namun, ....". Demikian juga penulisan kata "orangtua" yang dirangkai seharusnya ditulis terpisah "orang tua." Penulisan kata yang terpengaruh dengan bahasa ibu juga masih sering muncul, seperti kata "nafkah" justru ditulis salah menjadi "nafka". Beberapa kata yang terpengaruh dengan lafal kedaerahan atau lafal bahasa ibu memunculkan bahasa yang salah ketika ditulis, seperti kata "ke rumah" ditulis "keruma".

Adanya kekurangtepatan dalam mengembangkan isi, struktur cerita, pilihan kata, kalimat gaya bahasa, dan ejaan dalam menulis teks cerita di atas dapat diatasi dengan memperbanyak berlatih dengan memperhatikan aturan yang ada, seperti ejaan bahasa Indonesia dan tata bahasa baku bahasa Indonesia. Sebagaimana ditegaskan Perkins (dalam 
Hadley, 1993:343-345), kecermatan dalam menilai teks perlu didasarkan pada penilaian analitik tulisan mencakup struktur, isi, diksi, kalimat, dan mekanik atau ejaan dan bahkan organisasi makna yang sesuai dengan konteksnya.

\section{KESIMPULAN}

Berdasarkan hasil penelitian dan pembahasan dapat disimpulkan bahwa kemampuan menulis teks cerita mahasiswa kelas III-A Program Sarjana Pendidikan Bahasa Indonesia FKIP Universitas Bengkulu semester ganjil 2018/2019 telah mencapai kategori baik dengan skor rerata sebesar 73,97. Hasil ini berarti kelima aspek yang membangun kemampuan menulis teks cerita sudah berkualitas baik dan untuk mencapai hasil yang lebih baik perlu upaya perbaikan Secara khusus, pencapaian tiap-tiap aspek juga berkategori baik, yakni aspek (1) pengembangan isi sesuai tema memperoleh skor rerata 18,94 dengan sumbangan sebesar $20,5 \%$; (2) penggunaan struktur teks cerita memperoleh skor rerata 16,09 dengan sumbangan sebesar 21,7\%; (3) pilihan kata atau diksi mendapat skor rerata 14,38 dengan sumbangan sebesar $19,4 \%$; (4) penggunaan kalimat bergaya bahasa cerita mendapat skor rerata 17,24 dengan sumbangan sebesar 18,6\%; dan (5) mekanik berkaitan dengan penggunaan ejaan bahasa Indonesia mendapat skor rerata 7,32 dengan sumbangan sebesar $19,8 \%$.

\section{DAFTAR PUSTAKA}

Bachman, Lyle F. 1990. Fundamental Considerations in Language Testing. Oxford: Oxford University Press.
Djiwandono, Soenardi. 2008. Tes Bahasa Pegangan bagi Pengajar Bahasa. Jakarta: PT Indeks.

Hadley, Alice Omaggio. 1993. Teaching Language in Context. Boston: Heinle \& Heinle Publishers.

Heaton, J.B. 1988. Writing English Language Tests. New York: Longman Group UK Limited.

Jacobs, Holly L., et.al. 1981. Testing ESL Composition: A Practical Approach. Massacheserttes: Newbury House Publishers, Inc.

Johnson, Elaine B. 2002. Contextual Teaching and Learning: What it is and why it's here to stay. California: Corwin Press Inc.

Kementerian Pendidikan dan Kebudayaan RI. 2013. Bahasa Indonesia: Wahana Pengetahuan untuk SMP/MTs Kelas VII. Buku Siswa. Jakarta: Kementerian Pendidikan dan Kebudayaan.

Kementerian Pendidikan dan Kebudayaan RI. 2014. Buku Guru: Bahasa Indonesia Wahana Pengetahuan untuk SMP/MTs Kelas VII. Jakarta: Kementerian Pendidikan dan Kebudayaan.

Latief, Muh. Adnan. 2002. "Pengembangan Bahan Ajar Kontekstual Bahasa Inggris SLTP Cawu 2 untuk 6 Provinsi di Kalimantan dan Sulawesi”. Jurnal Penelitian Kependidikan, Tahun 12 Nomor 1, Juni.

Nurgiyantoro, Burhan. 2001. Penilaian dalam Pengajaran Bahasa dan Sastra Edisi ke-3. Yogyakarta: PT BPFE.

Nur, Muhammad. 2001. "Pengajaran dan Pembelajaran Kontekstual", Makalah Pelatihan TOT Guru Mata Pelajaran SLTP dan MTs, Juni.

Sevilla, Consuelo G., dkk. 1993. Pengantar Metode Penelitian. Terjemahan Alimuddin Tuwu. Jakarta: UI Press. 
Satori. 2013. "Komponen Kompetensi Profesional Guru", Pendidikanku: Informasi Pendidikan Terkini. Http://sdnwonoue.blogspot.com/2 013/08. Diunduh, 27 April 2015.

Wiratno, Tri. 2014. "Pembelajaran Bahasa Indonesia Berbasis Teks dalam Kurikulum 2013”. Materi Pelatihan Instruktur Nasional
Pembelajaran Bahasa Indonesia Berbasis Teks. Jakarta: Badan Pengembangan dan Pembinaan Bahasa.

Yulistio, Didi. 2012. "Pengaruh Strategi Pembelajaran dan Kemampuan Penalaran Terhadap Keterampilan Menulis", Disertasi Tidak Diterbitkan. Jakarta: UNJ. 